\title{
SUÇ VE MEDYA
}

\author{
Tuğçe ER*, Alev ELMAS**, Gökben HIZLI SAYAR***
}

\begin{abstract}
Özet
Bu çalışmada, radyo, televizyon, internet ve gazete gibi medya araçlarında yayınlanan suç ve şiddet içerikli programların kişiler üzerindeki etkileri incelenmiştir. Özellikle kriminoloji alanı içerisinde önemli bir yeri olan suç korkusunun oluşmasında medya şiddetinin tesiri de ele alınmıştır. Çocuk ve ergenlerde başta olmak üzere medyada yayınlanan suç davranışlarının gösteriliş şekilleri ve kullanılan dil gibi etkenler nedeniyle kişilerde suç korkusu, suça yönelme, öfke, saldırganlık ve çeşitli psikolojik rahatsızlıklar görülebileceği düşünülmektedir. Medya ve suç arasındaki ilişkiyi ortaya koymak üzere araştırmacılar tarafından geliştirilen kuram ve hipotezler açıklanmış, konu ile ilgili yapılan araştırmalara yer verilmiştir.
\end{abstract}

Anahtar Kelimeler: Medya, suç, şiddet.

* Psikoloji Doktora Programı Öğrencisi, Üsküdar Üniversitesi, Sosyal Bilimler Enstitüsü

** Psikoloji Doktora Programı Öğrencisi, Üsküdar Üniversitesi, Sosyal Bilimler Enstitüsü *** Doç. Dr., Üsküdar Üniversitesi, Sosyal Bilimler Enstitüsü 


\title{
CRIME AND MEDIA
}

\author{
Tuğçe ER*, Alev ELMAS**, Gökben HIZLI SAYAR***
}

\begin{abstract}
In this study, the effects of crime and violence programs on people were examined in media such as radio, television, internet and newspaper. The fear of crime, which has an important place particularly in the field of criminology, has been taken up in the influence of media violence. The fear of crime, criminal behavior, anger, aggression and various psychological disorders can be influenced first in children and adolescents and then in people due to the factors such as the representation of criminal behaviors displayed in the media and the language used. Theories and hypotheses developed by researchers are explained to reveal the relationship between media and crime, studies which arerelated to the subject have been included.
\end{abstract}

Keywords: Media, crime, violence.

* Doctoral Student in Psychology Program, Üsküdar University, Social Sciences Institute ** Doctoral Student in Psychology Program, Üsküdar University, Social Sciences Institute *** Associate Professor, Üsküdar University, Social Sciences Institute 


\section{Giriş}

Medya, günümüzde bireylerin sosyalleşme sürecinde, iş, aile, okul ve arkadaşların da içinde bulunduğu dış çevre ile olan ilişkiler kadar önemli yer tutmaktadır. Medyada suç içeren davranışların gösteriliş şekilleri, şiddeti normalleştirmeye kadar giden bir sürecin ortaya çıkmasına neden olabilmektedir (Güleç vd. 2012: 113). Değişik alanlarda yapılan bilimsel araştırmalar, kişilerin suç işlemesine neden olan faktörler üzerinde durmuştur. Konuyla ilgili yapılan araştırmalar, medya ve suç ilişkisini inceleyerek medyada gösterilen suç davranışlarının şiddet eğilimine neden olduğunu vurgulamıştır (Anderson vd. 2015: 7). Özellikle çocuk ve gençler tarafından izlenen şiddet ve saldırganlık temalı medya programlarının, agresyon, yüksek düzeyde uyarılmışlık hali, depersonalisazyon ve sosyal izolasyona neden olduğu bildirilmiştir (Bushman ve Huesmann, 2006: 348).

Insanlık tarihi kadar eski olan suç, medyanın var olmasıyla beraber, farklı görünümlerde ortaya çıkmıştır. Suç yelpazesi altında yer alan şiddet, eski dönemlerde, karşııkı yapılan savaş oyunları ve rekabet içeren oyunların bir parçasıyken, günümüzde teknolojinin ilerlemesiyle beraber denetimli bir şekilde medya araçlarının bir ürünü olarak yerini almıştır. Çeşitli medya organlarının toplumsal ve sosyal olaylarla beraber işlenmiş olan suçları iletme biçimi, kişilerin söz konusu olaylara bakış açısını büyük ölçüde etkilemektedir. Bu yüzden radyo, televizyon, bilgisayar, gazete gibi medya araçlarına, suç davranışlarının sosyal temsili açısından önemli görevler düşmektedir (Farrall vd. 2009: 112). Çeşitli medya platformlarının ortaya çıkmasıyla beraber, şiddet ve suçun, toplum tarafından alıılanma biçimi değişmiş ve şiddeti olduğundan azaltılmış şekliyle ortaya çıkmıştır (Yumrukuz, 2017: 92).

Radyo, televizyon, gazete ve internet gibi medya araçları, kitle iletişimine yönelik değişik tanımlar oluşturarak ve bazen objektif olmayan sunumlar yaparak bireylerin tutum ve algılarını etkileyebilmekte, duygu ve davranışların değişimine sebep olabilmektedir. Yükselen suç grafikleri medyaya yansıtılırken, düşen suç grafikleri ihmal edilebilmektedir. Kişiler, doğru olduğundan emin olmadan, medya araçları vasıtasıyla yayımlananları dikkate almaktadır. Dünyanın bireyler tarafından tehlikeli bir yer olarak algılanması ve özellikle toplumun duygularına yönelik dikkat çeken ve tepki oluşturan suç davranışlarının, olduğundan daha abartılı şekilde yayımlanması, bireylerde birtakım kaygıların oluşmasına sebep olmaktadır (Tulloch, 2000: 453). Bu yüzden medya araçlarının kişiler üzerindeki etkileri her dönemde araştırma konusu olmuştur.

Bu gözden geçirme yazısında, medya araçlarının suç kavramı üzerindeki etkileri geçmiş araştırmalardan yola çıkarak teorik olarak açıklanmaya çalışılmıştır. Bu çalışma daha önce bu konuda yapılan çalışmalar bağlamında literatüre katkı sağlamayı amaçlamaktadır. Konu ile ilgili daha önce yapılan çalışmalar için literatür taraması yapılmıştır. Konuya uygun, direkt bağlantılı olan güncel ve güvenilir kaynaklar tercih edilmiş ve konu bu çerçevede değerlendirilmiştir. 


\section{Medya ve Suç Korkusu}

Suç korkusu, kognitif, davranışsal ve duygusal bileşenleri olan kompleks bir sözcüktür, bu yüzden anlamıyla ilgili ortak bir görüş birliğinin sağlanması güçtür. Suç korkusunun kognitif bileşeni, tehlike olasılığı ortaya çıktığında mantıksal düşünme biçimini kapsarken, duygusal bileşeni, kaygı ve korku ile bağdaştırılan hislere atıf yapmaktadır. Davranışsal bileşeni ise suç davranışlarına yönelik verilen fiziksel yanıtları ifade eder (Franklin vd, 2008: 208). Ferraro'ya (1995: 72) göre suç korkusu, kişinin suç ile bağdaştırdığı simgelere yönelik oluşturduğu duygusal yanıt ya da kaygı hissidir. Warr (2000: 453): ise suç korkusunu, bilincine varılan dış dünyaya yönelik geliştirilen duygusal tepki şeklinde ifade etmiştir.

Gerbner ve arkadaşlarının (1979: 178) ortaya attıkları işleme kuramı yaklaşımına göre televizyon kişilerin dış dünya algısını biçimlendirmekte ve bozmaktadır. Televizyon seyretmenin en önemli zararlarından birinin tehlikelerle dolu bir dünyada yaşanan yüksek düzeyde ve tutarsız suç korkusu olduğunu bildirilmiştir.

ABD'de Kanun Uygulama ve Adalet Dairesi Başkanlık Komisyonunca 1966 yılında hazırlanan raporda, vatandaşların \%43'ünün suç korkusu sebebiyle geç saatte evden çıkamadığı, \%35'inin tanımadığı kişilerle iletişim kurmaktan kaçındığı, \%21'inin geç saatte arabasını alarak dışarı çıktığı, \%20'sinin ise suç mağduriyeti korkusu nedeniyle farklı bir yerleşim yerine taşınmak istediği bildirilmiştir (Jackson, 2006: 260).

Literatür incelendiğinde, medya ve suç korkusunu inceleyen çok sayıda çalışmaya rastlanmaktadır. Bir çalışmada, medya programlarını düzenli olarak takip edenlerin, dış dünyada olanları medyada izlediklerine göre anlamlandırma ihtimallerinin yüksek olduğu tespit edilmiştir. Florida eyaletinde 2092 kişilik bir örneklem grubuyla yaptığı çalışmada, düzenli olarak televizyon ve radyodaki suç içerikli haberleri izleyenlerin, suç korkularının istatistiksel olarak anlamlı bir şekilde yüksek olduğu tespit edilmiştir (Chiricos vd. 2000: 780).

Winkel ve Vrij (1990) kadınlardan oluşan bir örneklem grubunda, gazetede okunan tecavüz haberlerinin suç korkusu üzerindeki etkisini incelemiştir. Araştırma sonuçlarından elde edilen verilere göre, suç korkusu, gazete haberlerini takip etmeyen grupta en az, mahalli gazete haberlerini takip eden grupta en fazla, mahalli olmayan gazete haberlerini takip eden grupta ise orta düzeyde bulunmuştur. Çalışmada tecavüzün gerçekleştiği yer ile korku tepkisi arasındaki ilişkinin gücüne dikkat çekilmiştir. Ayrıca suçun meydana geldiği çevre ile kişinin oturduğu çevrenin benzer olarak algılanmasının suç korkusu üzerinde etkili olduğu bildirilmiştir. Araştırmacıların altını çizdiği diğer bir konu da, kişinin kendisini kurbana yakın bulmasının ve kadınların özellikle korktuğu suçu gazetede okumalarının etkisidir (Winkel ve Vrij, 1990: 259).

Amerika Birleşik Devletleri'nde ülke çapında yapılan bir çalışmada, 379 kişiyle yapılan telefon konuşmaları neticesinde, televizyon seyretmenin, uzak 
şehirlerde suç korkusunu arttırdığı, fakat bulundukları bölge ve çevresinde herhangi bir etkisinin olmadığı saptanmıştır (Heath ve Petratitis, 1987: 117). Yapılan diğer bir çalışmada, kişileri silahlanmaya yönlendirmesi ve suç korkusunu yükseltmesi bakımından, yerel televizyon kanallarında izlenen haberlerin etkili oluğu tespit edilmiştir (Holbert vd. 2004: 350). Los Angeles şehrinde yapılan başka bir çalışmada, televizyon izleyenlerin sayısının yüksek olduğu yerlerde, suç istatistikleri başka yerleşim yerlerine göre düşük olsa da, yüksek düzeyde suç korkusunun olduğu saptanmıştır (Matei ve Ball-Rokeach, 2005: 320). İngilteresde okunan gazetelere yönelik yapılan bir araştırmada, daha dikkat çekici üçüncü sayfa haberlerinin bulunduğu gazeteleri takip edenlerin suç korkusunun yüksek olduğu ortaya konmuştur. Aynı araştırmada geliri daha az olan okuyucular için hazırlanmış küçük ebatlardaki gazetelerden okunan haberlerin, daha büyük ebatlarda hazırlanmış gazetelerden okunan haberlere kıyasla üç kat daha fazla suç korkusuna neden olduğu saptanmıştır (Williams ve Dickinson, 1993: 42). Belçika'da, 18 yaşın üzerindeki 711 kişilik bir örneklem grubuyla yapılan bir çalışmada, televizyon seyretme ve suç korkusu arasında anlamlı bir ilişki saptanmıştır. Bu araştırmada, kadınların suç korkusunun erkeklere kıyasla daha fazla olduğu bildirilmiştir (Custers ve van den Bulck, 2011: 117). Kitle iletişim araçlarının suç korkusuna yönelik tesirine bakılan farklı bir araştırmada, TV'deki suç haberlerine yönelik dikkatin yüksek düzeyde suç korkusu oluşturduğu ancak bu sonucun gazete haberleri için söz konusu olmadığı tespit edilmiştir (O'Keefe ve Reid-Nash, 1987: 150).

Ülkemizde ise kitle iletişim araçları ve suç korkusu arasındaki ilişkiyi ortaya koyması bakımından Erdönmez'in (2009) araştırması dikkati çekmektedir. Araştırmada İstanbul ilinde bulunanların, suç mağduriyeti korkusuna medyanın tesiri incelenmiştir. Araştırma sonuçlarına göre, TV seyredenlerin suç korkusunun farklı medya araçlarını kullananlara göre daha fazla olduğu tespit edilmiştir (Erdönmez, 2009: 69).

1950'li yıllardan itibaren medya araçlarının çoğalmasıyla beraber topluluklar arasında ahlaki yozlaşma yaşanacağı kaygısı meydana gelmiştir. Bu ahlaki yozlaşmayla birlikte gitgide yükselen suç istatistikleri, kişilerde tehlike algısı, korku ve paniğin oluşumuna sebep olmuştur. Çocukların medyada özellikle pedofili kurbanı etiketiyle haberlere sıkça konu olması var olan paniğin artmasına neden olmaktadır (Jewkes, 2004: 150).

\section{Suçun Medyaya Taşınması ve Etkileri}

Medya suçlulukla ilgili hareketlenmeleri, suç işleyenlerin eylemlerinin sıklığını ya da dönemsel yükselmelerin öznel tesirlerini ortaya koyan bir araçtır. Medyada suçlulukla ilgili böyle bir hareketlenme, 1976 senesinin sonlarına doğru New York şehrinde görülmüştür. New York Daily News, New York Times, New York Post isimli gazeteler ve buna paralel olarak New York'a bağlı birkaç televizyon kanalı, yaşlılara karşı işlenen suçların arttığını bildirmişlerdir. Yaklaşık olarak yedi hafta devam eden bu yayınlar, bütün Amerikan gazete, televizyon 
ve mecmualarına da konu olmuştur. Yaşlılara yönelik işlenen suçlar; cinayet, gasp ve tecavüz eylemleriyken, bu suçların failleri ise genç zencilerdi. Beyaz ırktan olan bu yaşlıların, fakirlik gibi bazı nedenlerden ötürü zenciler tarafından saldırıya uğradığı bildiriliyordu. Yaşlılara yönelik işlenen bu suçlar 1976 yılının Kasım, Aralık aylarında gazeteciler tarafından haber yapılmıştır. Polis kayıtlarına geçen, 1976 yılının Kasım ve Aralık aylarına ait suç oranları incelendiğinde, yaşlılara yönelik suçlarda yükselme gözlenmemiştir. Hatta gerçek istatistikler yaşlılara karşı işlenen suçlarda azalma olduğunu gösteriyordu. Medyada yayılan yaşlılara yönelik suçların arttığı doğrultusundaki haberlerin gerçeği yansıtmadığı açıktı. Buna rağmen 1977 yılının Mayıs ayında yapılan bir ankette, ankete katılan 50 yaşın üzerindeki kişilerin yarısının, önceki yıla göre sokakları daha tehlikeli bulduğunu bildirdiği kaydedilmiştir. Medyada gösterilen haberler, toplumsal yaşama müdahale etmekte ve özellikle suç haberlerinin yayınlanması, güvenlikle ilgili kaygıları gündeme getirmektedir (Demirbaş, 2001: 97).

Çağımızda her evde, medya araçları arasında önemli bir yere sahip olan, televizyonun olması, televizyon izleyenlerin sayısının günden güne artmasına ve kişilerin dikkatini çekecek programların yapılmasına sebep olmaktadır. Halk tarafından sıklıkla izlenen diziler, belgeseller ve haber programlarında suçun yer alması, kişilere suçun gündelik hayatta sürekli bulunan bir tema olduğu fikrini aşılamaktadır. Bu sebeple kişilerde suçla ilgili algı ve izlenimler, medyada izlenen şekliyle oluşmaktadır. Amerika'da yapılan bir araştırmada, toplumun \%76'sının suç algısının, gazetelerde okunan ve televizyon kanallarında izlenenlere göre şekil aldığı, yalnızca \%22'sinin suça yönelik bireysel bir tecrübesi olduğu saptanmıştır (Marsh ve Melville, 2009: 117).

Kişilerin hayatlarının önemli bir bölümünü ele geçiren medya araçlarının birtakım olumsuz etkilerinden bahsedilmektedir:

1) Hoş olmayan birtakım görsellere maruz kalmanın kişilerde olumsuz ve düşmanca duygulara neden olması

2) Sosyal hayattan uzaklaşmanın getirisi olarak, iletişim kurmada güçlük

3) Menfi görsellerin yayınlanması

4)Saldırganlık içeren eylemlerin bulunması ve bunların alışkanlık oluşturup, özendirici olması

5) Suç korkusunun oluşmasına sebep olması

6) Yanlı yapılan yayınlar yoluyla birtakım politik hedeflere hizmet edilmesi (Demirbaş, 2001: 118).

Suç ve saldırgan davranışların medyada izlenenler yoluyla öğrenildiğini gösteren deneylerden biri Bandura tarafından 1965 yılında yapılmıştır. Bu deneyde, okul öncesi çocuklara, erişkin bir kişinin, yetişkin ölçülerindeki Bobo adı verilen bir bebeğe, dört farklı şiddet eylemi uyguladığı bir TV görseli iz- 
letilmiştir. İzletilen programın üç farklı bitişi bulunmaktadır. Her gruba farklı sonlar seyrettirilmiştir. ilk gruba, bir kişinin, şiddet uygulayan çocuğu şeker, takdir ve içecekle ödüllendirdiği biçimindeki son, sonraki gruba, gazeteyle hafif bir şekilde vurularak şiddet davranışının ikaz edildiği biçimindeki son, en son gruba da şiddet davranışılla ilgili herhangi bir geri bildirimin alınmadığı son seyrettirilmiştir. Sonraki süreçte okul öncesi çocuklara 10 dakika boyunca serbest oynamaları için izin verilmiştir. Çocukların oyun oynadığı yerde, Bobo bebek ve gördüklerini taklit etmelerini sağlayacak çeşitli eşya ve materyaller bulunmaktadır. Saldırgan davranışın takdir edildiğini izleyen çocukların, ceza verilen bitişi seyreden çocuklara kıyasla, izlediklerini taklit etmeye daha meyilli oldukları kaydedilmiştir. Uygulanan şiddete yönelik herhangi bir geribildirim görmeyen grubun davranış biçimleri saldırgan davranışın övüldüğünü izleyen grubun davranış biçimleriyle paralellik göstermiştir. Bandura'nın toplumsal öğrenme adını verdiği kuramına göre, saldırgan davranış, medya araçları vasıtasıyla çocuklar tarafından şiddet içerikli eylemler gözlemlenerek öğrenilir (Burger, 2006: 37).

Televizyon gibi kitle iletişim araçlarında, şiddet ve suç içeren görsellere maruz kalmanın saldırganlığı azaltacağını öne süren yaklaşımlar da vardır. 'Katarsis' adı verilen bu yaklaşıma göre bireyin olumsuz mental ve fiziksel enerjiyi atabilmesi ve stresini doğru şekillerde yönlendirebilmesi gereklidir. Gündelik hayatta sözel ve fiziksel şiddet içeren durumlara sıkça maruz kalmanın saldırganlık enerjisini yükseltmesi sonucu kişi bu enerjiyi boşaltacak kanallar arar. Bu kanallardan biri de televizyonda kurgulanmış şiddet görsellerinin izlenmesidir. Bu hipoteze göre televizyon olumsuz enerjinin boşalımı için gerekli olan materyali sunarak saldırganlığın azalmasına yardımcı olur (Liebert ve Sprafkin, 1988: 93). Gerbner (2014) ise, televizyondaki suç ve şiddet içerikli görsellerin, seyircileri saldırganlığa teşvik etmektense, dış dünyanın tehlikelerle dolu bir yer olduğuyla ilgili izlenimini güçlendirdiğinden bahsetmektedir. Bu araştırmacıya göre kitle iletişim araçlarından televizyon, kişilerde kaygı ve güvensizliği tetikleyerek, sosyal düzene zarar vermekte, kadınlar ve yaşlılara yönelik algıyı bozarak hususi bir kuvvet dengesinin oluşmasına neden olmaktadır (Gerbner, 2014: 22).

Tannenbaum'un uyarma kuramına göre medya araçları vasıtasıyla suç içeren davranışlara tanık olma, izleyicilerin baş etme yolu ve problem çözme davranışı olarak şiddet eylemlerine başvurmasına neden olarak, kişilerde heyecan duygusu yaratmakta ve uyarıcı etkide bulunmaktadır. Bu bakış açısına göre, negatif uyaranlara çok fazla maruz kalma kişilerde bir süre sonra hiperaktivite belirtilerinin oluşmasına sebep olmaktadır (Tannenbaum ve Zillmann, 1975: 156).

Özgül olarak duyarsızlașma sürecini inceleyen araştırmalarda, duyarsızlık, olumsuz bir etkiye tekrarlı bir şekilde maruz kalınması sonucu, uyarana verilen tepkinin giderek azalması olarak ifade edilmektedir. Duyarsızlık, başka bir araştırmada, herhangi bir etkiye maruz kalındığında, verilen kognitif, davra-

\section{2 ETKileşim |Yıl1|Sayı2|Ekim 2018}


nışsal ve duygusal tepkilerin azalması ya da yok olması şeklinde açıklanmıştır (Funk vd. 2004: 27). Medyada şiddet ile ilgili uyaranların sıkça yayınlanması, bir süre sonra bireylerde duyarsızlaşma etkisine neden olabilmektedir (Fanti vd. 2009: 182). Aşırı uyarılmanın sonucu olarak, şiddet görüntülerine karşı verilen normal psikolojik tepkiler yerini donukluğa bırakmaktadır. Bu donukluk ve duyarsızlaşma durumu, medyanın şiddet dolu mesajları, saldırganlığı kabul edilebilir bir duruma getirdikçe artmaktadır. Dizi filmlerde şiddete şiddetle karşılık verilmesi bu durumun en özgül örneklerindendir (Mutlu, 2005: 112).

Literatürde kitle iletişim araçlarının etki çalışmaları incelendiğinde medyanın yabancılaşmaya da neden olduğunu savunan görüşlere rastlanmaktadır. Yabancılaşma, sosyal ilişki kurmada güçlük, kişilerin kendi içlerinde ya da toplumdaki diğer gruplarla arasına belli bir sınır koyması ve kendisini izole etmesi olarak ifade edilir. Bazı araştırmacılara göre, yüksek derecede yabancılaşma, kendine ve çevreye karşı güvensizlik sorunu, net olmama, belli bir hedefin olmaması, karar almada sorun yaşama, ileri düzeyde kaygı, yetersizlik duygusu ve kendini izole etme gibi birtakım his ve davranışları aktive edebilmektedir (Jones vd. 1985: 1507). Bir başka çalışmada medyanın yabancılaşmaya yönelik çok kuvvetli bir tesirinin olduğunu ve bunun yansıması olarak sosyal ortamlarda bir çeşit umursamazlık ve aldırmazlık halinin oluştuğunu bildirmektedir (Turska-kawa, 2011: 20).

Berkowitz ve arkadaşlarının (2003: 109) yaptığı bir çalışmaya göre medya programlarındaki suç davranışlarına kısa süreli maruz kalan kişilerde, sözel şiddete başvurma, şiddet içerikli düşünce ve duygularda artma ve kaygı durumu yaşanırken, uzun dönemde kaba kuvvet içeren tepki ve davranışlarda bulunma saptanmıştır. Televizyonda şiddet içerikli görsellerin izlenmesiyle suç eğilimi arasındaki ilişkinin araştırıldığı bir meta-analiz araştırmasında, televizyonda suç içerikli görsellere maruz kalmanın çocuk ve ergenlerin suç işlemesinde 13 kat daha fazla etken olduğu tespit edilmiştir (Paik ve Comstock, 1994: 520).

Şiddet davranışlarının medyaya taşınmasıyla ilgili yapılan akademik çalışmaların tarihinin 1960 yılının öncesine dayandığı ve bu konuda büyük çapta bir görüş birliği olduğu bildirilmiştir. Bu çalışmalara göre, saldırgan davranış ya da suç eylemlerinin pek çok sebebi bulunmasına karşın, bu sebeplerin hiçbirinin kendi başına yeterli olmayacağı fakat bu sebeplerden her birinin aktive edici bir durumla beraber şiddet ihtimalini arttırabileceği ortaya konmuştur (Anderson vd. 2015: 12).

51.000 kişilik bir örnekleme sahip, 280 farklı araştırmanın metaanaliz çalışmasında medyadaki şiddet davranışlarına tanık olmanın dört temel negatif etkiye neden olduğu belirtilmiştir: Birinci etki olarak; suç davranışlarının yayımlandığı medya araçlarına maruz kalmanın çocuk ve yetişkinlerin saldırganlık düzeyinde ve şiddete yönelmesinde artışa neden olduğu vurgulanmaktadır. İkinci etkiye göre, şiddet içeren medya görüntülerine tanık olmak, dış çevre ve dünyanın tehlikeli bir yer olarak algılanmasına ve kişilerin korunmak için birtakım önlemler almaya yönelmesine neden olmaktadır. Üçüncü etki duyar- 
sızlaşmaktan bahsetmektedir. Bu tür medya araçlarına maruz kalan kişilerin şiddet içeren olaylara ve suç kurbanlarına karşı duyarsızlaştığı vurgulanmaktadır. Dördüncü etkiye göre çocuk ve yetişkinler, suç davranışlarını içeren medya araçlarına maruz kaldıkça, saldırganlık dozu gittikçe artan görsel materyale ulaşma yönünde eğilim göstermektedir (Donnerstein vd. 1994: 227).

Medyadaki olumsuz görseller ve suç içeren davranışlar arasındaki ilişkiye dikkat çeken 3500'den çok araştırmanın sadece 18'inde, medya ve ortaya konan tepkiler bakımından olumlu bir ilişki tespit edilmiştir. Kamusal pek çok araştırmaya göre, medyada yayınlanan suç içerikli yayınlarla beraber şiddete dayalı tepkilerde artış gözlendiği ortaya konmuştur. Meta-analizleri yapılan 28 ve 217 araştırmadan oluşan iki çalışmada, medyadaki saldırgan davranışların topluma aykırı tepkilere neden olduğu ortaya konmuştur (Villani, 2001: 398).

Küçük öyküler verilip, kişilerarası problem çözme becerileri incelenen bir araştırmada, medyadaki şiddet görüntülerini izleyenlerin daha saldırgan tepkilere başvurduğu gözlenmiştir (Bushman ve Anderson, 2002: 1680). 2009 yılında yapılan diğer bir araştırmada ise, şiddet içerikli televizyon filmlerine maruz kalan bireylerin, tanımadıkları yaralanmış kişilere yardım ederken daha ağır davrandıkları ortaya konmuştur (Bushman ve Anderson, 2009: 274).

Literatürde medyada yayınlanan terör olaylarının kişiler üzerindeki etkilerini inceleyen çok sayıda araştırmaya rastlanmaktadır. Amerika Birleşik Devletleri'nde 2002 yılında 2273 kişilik bir örneklem grubunda yapılan çalışmada, katılımcıların 11 Eylül terör saldırılarıyla ilgili psikolojik durumları değerlendirilmiştir. Bu araştırmanın sonuçlarına göre, New York'ta bulunan katılımcıların \%11,2'sinde, Washington şehrinde bulunan katılımcıların \%2,7'sinde, diğer büyük şehirlerdeki katılımcıların \%3,6'sında ve geri kalan bölgelerdeki katılımcıların \%4'ünde travma sonrası stres bozukluğuna rastlanmıştır. Travma sonrası stres bozukluğu semptomlarıyla bağlantılı bulunan değişkenler, cinsiyet, yaş, olayı direkt yaşantılama, 11 Eylül terör saldırısı ve olayın sonrasında televizyonda konuyla ilgili haberleri takip etme süresi olarak belirlenmiştir. Terör saldırısıyla ilgili haberlerin izlenme süresi, psikolojik semptomların ortaya çıkması açısından anlamlı bulunmuştur (Schlenger vd. 2002: 585).

Pfefferbaum ve arkadaşlarının (2000: 362) yaptığı bir araştırmada, 1995 yılında Oklahoma kentinde bulunan Murrah federal binasına yapılan bombalı saldırıdan 2 sene sonra, 6. sınıfa devam eden 69 kişilik bir öğrenci grubunda saptanan travma sonrası stres bozukluğu ve işlevsellik kaybı semptomları, medyada saldırı ile ilgili görselleri takip etmeyle ilişkilendirilmiştir.

\section{Tartışma}

Teknolojinin hızla gelişmesi, televizyon, radyo, internet ve gazete gibi kitle iletişim araçlarının önem kazanmasına sebep olurken geniş kitlelerin kısa sürelerde ortak bilgiye ulaşmasına da olanak sağlamaktadır. Medya araçlarının gündemdeki bilgilere hızlıca erişim kolaylığı sağlamasının yanı sıra, eğlendir-

\section{$64 \mid$ eTKíleşim | Yıl1|Sayı2| Ekim 2018}


me, boş zaman geçirme, alış-veriş yapma, haberleşme ve eğitme gibi olumlu katkıları da yadsınamaz. Bu kadar geniş bir bilgi havuzunda eğlendirici, öğretici bilgilerin yanında suç ve şiddet gibi gösteriliş şekilleriyle özellikle çocuk ve gençleri olumsuz etkileyen görseller de yer almaktadır. Medya, toplumda etik ilkelerin esasını meydana getiren ahlaki inançlar ve ölçütleri belli bir perspektifte güçlendirirken bir taraftan da kişinin benlik saygısına ve dış dünyaya adaptasyonuna tesir etmektedir.

Suç yelpazesi altında yer alan şiddet, teknolojinin gelişmesiyle günümüzde medya araçlarının bir ürünü olarak da karşımıza çıkabilmektedir. Medyada suç davranışlarının gösteriliş şekilleri kişileri ve dolayısıyla toplumun bakış açısını büyük ölçüde etkilemektedir. Bu yüzden radyo, televizyon, bilgisayar, gazete gibi kitle iletişim araçlarına, suç davranışlarının sosyal temsili açısından önemli görevler düşmektedir.

Literatür incelendiğinde medyada yayınlanan şiddet ve suç temalı görüntülerin kişiler üzerindeki olumsuz etkilerine sıkça rastlanmaktadır. Bu bağlamda son zamanlarda öne çıkan kavramlardan biri de suç korkusudur. Yapılan araştırmalardan elde edilen bulgular doğrultusunda, medyada suç davranışlarına sıkça maruz kalmanın yüksek düzeyde suç korkusuna neden olduğu ve kişilerin dış dünyayı medyada izlediklerine göre anlamlandırdığı bildirilmektedir. Kişinin oturduğu çevreyi, medyada izlediği suçun gerçekleştiği çevreye benzetmesinin ve seyircinin kendisini suç mağduruyla özdeşleştirmesinin suç korkusu üzerinde etkili olduğunu tespit eden araştırmalar da bulunmaktadır (Winkel ve Vrij, 1990: 251). Yapılan araştırmalar kitle iletişim araçlarından televizyonun suç korkusu üzerindeki etkisinin yanı sıra kişilerin dış dünya algısını biçimlendirdiğinden de bahsetmektedir.

Medya, suçu mağdur ve fail açısından ele alan, suçlulukla ilgili dönemsel iniş çıkışları ortaya koyan bir araç olması bakımından önemli olmasına karşın maalesef her zaman gerçeği yansıtmamaktadır. Medyada gösterilen haberlerin etkilerine yönelik yapılan çalışmalarda medyanın, toplumsal yaşama müdahale ettiği, özellikle suç haberlerinin yayımlanmasının ve kullanılan dilin, güvenlikle ilgili kaygıları şekillendirebildiği bildirilmiştir.

Medyada yayınlanan suç davranışlarına maruz kalmanın etkileri ve bunun yansıması olarak kişilerde şiddet ve saldırganlığın nasıl ortaya çıktığı ile ilgili çeşitli kuram ve hipotezler ortaya atılmıştır. Bu konuya açıklama getiren kuramlar; Bandura'nın toplumsal öğrenme kuramı, Tannenbau'ın uyarma kuramı, duyarsızlaşma hipotezi, yabancılaşma hipotezi ve katharsis kuramlarıdır. Bandura'nın toplumsal öğrenme kuramına göre, saldırgan davranış, medya araçları yoluyla şiddet içerikli eylemler gözlemlenerek öğrenilir. Tannenbaum‘un uyarma kuramına göre, şiddet uyaranlarına çok fazla maruz kalma kişilerde bir süre sonra uyarıcı etkide bulunarak hiperaktivite belirtilerinin oluşmasına sebep olmaktadır. Duyarsızlaşma hipotezine göre, medyada suç uyaranlarının sıklıkla yayınlanması, bir süre sonra bireylerde duyarsızlaşmaya ve aşırı uyarılmanın sonucu olarak tepkisizliğe neden olmaktadır. Tüm bu yaklaşımların 
varlığına karşın, medyadaki şiddetin kişilerdeki saldırganlığı azaltacağını savunan hipotezler de vardır. Katharsis hipotezine göre televizyonda kurgulanmış şiddet görsellerinin izlenmesi olumsuz enerjinin boşalımı için gerekli materyali sağlayarak saldırganlığın azalmasına yardımcı olur.

\section{Sonuç}

Sonuç olarak, çeşitli psikolojik belirtiler, suç mağduriyeti korkusu, ahlaki panik ve ahlaki yozlaşma, öfke ve saldırganlık gibi birçok etkisi göz önünde bulundurulduğunda, medyada ele alınan suçun kişiler üzerinde önemli bir rolü olabilmektedir. Bu da medyanın suç görsellerini yayımlanması, kullandığı dil ve yayımlanma saatleri gibi konulardaki hassasiyetini arttırması gerektiği ile ilgili sorumluluğunu gündeme getirmektedir.

\section{Kaynakça}

Anderson, C. A., Bushman, B. J., Donnerstein, E., Hummer, T. A., Warburton, W. (2015). "SPSSI Research Summary on Media Violence". Analyses of Social Issues and Public Policy. 15(1). 4-19.

Berkowitz, L., Anderson, C., Donnerstein, E., Huessman, L., Johnson, J., Linz, D., Wartella, E. (2003). "The influence of media violence on youth". Psychological Science in the Public Interest. 4(3). 81-110.

Burger, J. M. (2006). Kişilik. (í. D. Sarıoğlu, çev.) İstanbul: Kaknüs Yayınları.

Bushman, B. J. ve Anderson, C. A. (2002). "Violent Video Games and Hostile Expectations: A Test of the General Aggression Model". Personality and Social Psychology Bulletin. 28. 1679-1686. (2009). "Comfortably Numb". Psychological Science. 20(3). 273-277.

Bushman, B. J. ve Huesmann, L. R. (2006). "Short Term and Long Term Effects of Violent Media on Aggression in Children and Adults". Archives of Pediatrics \& AdolescentMedicine. 160. 348-352.

Chiricos, T., Padgett, K., Gertz, M. (2000). "Fear, Television News, and the Reality of Crime". Criminology. 38(3). 755-786.

Custers, K. ve van den Bluck, J. (2011). "Mediators of the Association Between Television Viewing and Fear of Crime: Perceived Personal Risk and Perceived Ability to Cope". Poetics. 39. 107-124.

Demirbaş, T. (2001). Kriminoloji. Ankara: Seçkin Yayıncılık.

Donnerstein, E., Slaby, G., Eron, L. D. (1994). "The Mass Media and Youth Aggression". L. D. Eron, J. H. Gentry, P. Schlegel (eds.) Reason to Hope: A Psychosocial Perspective on Violence \& Youth. (219-250). Washington: American Psychological Association.

Erdönmez, E. (2009). The Effect of Media on Citizens' Fear of Crime in Turkey. (Yüksek Lisans Tezi). ABD: University of North Texas.

\section{6 etKileşim |Yıl1|Sayı2| Ekim 2018}


Fanti, K. A., Vanman, E., Henrich, C. C., Avraamides, M. N. (2009). “Desensitization to Media Violence Over a Short Period of Time". Aggressive Behavior. 35.179-187.

Ferraro, K. F. (1995). Fear of Crime: Interpreting Victimization Risk. New York: State University of New York.

Franklin, T. W., Franklin, C. A., Fearn, N. E. (2008). "A Multilevel Analysis of the Vulnerability, Disorder, and Social Integration Models of Fear of Crime". Social Justice Research. 21(2). 204-227.

Funk, J. B., Baldacci, H. B., Pasold, T., Baumgardner, J. (2004). “Violence Exposure in Real-Life, Video Games, Television, Movies, and the Internet: Is There Desensitization?". Journal of Adolescence. 27(1). 23-39.

Gerbner, G., Gross, L., Morgan, M., Signorielli, N. (1979). "The Demonstration of Power: Violence Profile". Journal of Communication. 26. 172-199.

Gerbner, G. (2014). Medyaya Karşı. (G. Ayas, V. Batmaz, i. Korkmaz, çev.). i̇stanbul: Ayrıntı Yayınları.

Güleç, H., Topaloğlu, M., Ünsal, D., Altıntaş, M. (2012). “Bir Kısır Döngü Olarak Şiddet". Psikiyatride Güncel Yaklaşımlar. 4(1). 112-137.

Heath, L. ve Petraitis, J. (1987). "Television Viewing and Fear of Crime: Where is the Mean World?". Basic and Applied Social Psychology. 8(2). 97-123.

Holbert, R. L., Shah, D. V., Kwak, N. (2004). "Fear, Authority, Andjustice: Crime-Related TV Viewing and Endorsements of Capital Punishment and Gun Ownership". Journalism and Mass Communication Quarterly. 81(2). 343-363.

Jackson, J. (2006). "Introducing Fear of Crimeto Risk Research". Risk Analysis. 26(1). 253-264.

Jewkes, Y. (2004). Media and Crime. Britanya: Sage Publication.

Jones, W. H., Carpenter, B. N., Quintana, D. (1985). "Personality and Interpersonal Predictors of Loneliness in Two Cultures". Journal of Personality and Social Psychology. 48(8). 1503-1511.

Liebert, R. M. ve Sprafkin, J. (1988). The Early Window: Effects of Television on Children and Youth. New York: Pergamon.

Marsh, I. ve Melville, G. (2009). Crime, Justice and the Media. ABD: Routledge.

Matei, S. A., Ball-Rokeach, S. J. (2005). “Watts, the 1965 Los Angeles Riots, and the Communicative Construction of the Fear Epicenter of Los Angeles". Communication Monographs. 72(3). 301-323.

Mutlu, E. (2005). Globalleşme, Popüler Kültür ve Medya. Ankara: Ütopya Yayınevi.

O'keefe, G. J. ve Reid-Nash, K. (1987). "Crime News and Real World Blues". Communication Research. 14. 147-163.

Paik, H., ve Comstock, G. (1994). "The Effects of Television Violence on Antisocial Behavior: A Meta-Analysis". Communication Research. 21(4). 516-546.

Pfefferbaum, B., Seale, T. W., McDonald, N. B., Brandt Jr, E. N., Rainwater, S. M., Maynard, B. T. (2000). "Posttraumatic Stress Two Years after the Oklahoma 
City Bombing in Youths Geographically Distant from the Explosion". Psychiatry: Interpersonal and Biological Processes. 63(4). 358-370.

Schlenger, W. E., Caddell, J. M., Ebert, L., Jordan, B. K., Rourke, K. M., Wilson, D. (2002). "Psychological Reactions to Terrorist Attacks: Findings from the National Study of Americans' Reactions to September 11". JAMA: Journal of the American Medical Association. 288(5). 581-588.

Tannenbaum, P. H. ve Zillmann, D. (1975). "Emotional arousal in the facilitation of aggression through communication". Advances in Experiment Social Psychology. 8. New York: Academic Press.

Tulloch, M. (2000). "The Meaning of Age Differences in the Fear of Crime". British Journal of Criminology. 40. 451-467.

Turska-Kawa, A. (2011). "The (Dis)alienating Function of the Media. The Role of Mass Media in Building a Civil Society". Psychology of Language and Communication. 15(2). 1-27.

Villani, S. (2001), "Impact of media on children and adolescents: a 10-year review of the research". J Am Acad Child Adolesc Psyhiatry. 40(4). 392-401.

Warr, M. (2000). "Fear of Crime in the United States: Avenues For Research and Policy". David Duffee (ed.) Criminal Justice 2000: Measurement and Analysis of Crime and Justice (Vol. 4). (451-489). Washington: U.S. Department of Justice.

Williams, P. ve Dickinson, J. (1993). "Fear of Crime: Read All About It?: The Relationship between Newspaper Crime Reporting and Fear of Crime". British Journal of Criminology. 33. 33-56.

Winkel, F. W. ve Vrij, A. (1990). "Testing a Theory of Psychological Incapacitation of the 'Stressor' Based on Downward Comparison Processes". International Review of Victimology. 1. 251-265.

Yumrukuz, Ö. (2017). “Şiddete Karşı Duyarsızlaşma ve Sosyal Medya Ilişkisi Üzerine Bir İnceleme". Marmara iletişim Dergisi. 28. 89-106. 
\begin{tabular}{l|l} 
ETKILEşim & 69
\end{tabular} 